\title{
Restriction Fragment Length Polymorphism Analyses of Iranian Strains of Xanthomonas campestris from Cereals and Grasses
}

\author{
A. Alizadeh, Pathologie Végétale, Laboratoire d'Ingénierie Agronomique, Ecole Nationale Supérieure Agron- \\ omique. 145, Avenue de Muret. F- 31076 Toulouse-Cedex France (ENSAT); M. Arlat, Laboratoire de Biologie \\ Moléculaire des Interactions Plantes-Microorganismes, CNRS-INRA, BP 27, F- 31326 Castanet Tolosan Cedex, \\ France (INRA); A. Sarrafi, ENSAT; C. A. Boucher, INRA; and G. Barrault, ENSAT
}

\begin{abstract}
Alizadeh, A., Arlat, M., Sarrafi, A., Boucher, C. A., and Barrault, G. 1997. Restriction fragment length polymorphism analyses of Iranian strains of Xanthomonas campestris from cereals and grasses. Plant Dis. 81:31-35.

Restriction fragment length polymorphism (RFLP) analyses of the genomic DNA of 45 Xanthomonas campestris strains from cereals and grasses in Iran, and of 17 reference strains, were performed using two probes originating from X. campestris and including hrp genes. The Iranian strains studied belonged to three clearly distinct RFLP groups related to the grouping previously established on the basis of biochemical and physiological characters and host range. RFLP group 1 encompassed all the strains pathogenic to barley but not to the other plants tested (i.e., wheat, rye, Bromus inermis, Lolium multiflorum, Agropyron elongatum, and oat). RFLP group 2 contained strains that are pathogenic to all the above mentioned plants except oat. One strain, which has the same host range as group 2, was classified as RFLP group 3. Reference strains were distributed over these three groups, independently of their geographical origin. Strains in groups 1 and 3 had highly conserved RFLP patterns. In contrast, group 2 strains were easily split into two RFLP subgroups, although they did not differ significantly for other characters. The data suggest that RFLP analysis is a useful tool to distinguish among $X$. campestris strains causing bacterial leaf streak of cereals.
\end{abstract}

Additional keyword: black chaff

Bacterial leaf streak of cereals caused by different pathovars of Xanthomonas campestris (Pammel) Dowson is present in many regions of the world where cereals are grown (7). This pathogen causes serious yield losses in wheat under high rainfall temperate conditions (8).

Five pathovars of $X$. campestris were reported as causal agents of leaf streak of cereals and were distinguished by their pathogenicity toward one or more gramineaceous plants: $X$. campestris pv. hordei (Hagborg) Dye 1978 (formerly X. translucens [Jones et al., 1917] Dowson 1939) is defined as being pathogenic only to barley $(12,14) ; \quad X$. campestris pv. undulosa (Smith, Johnson and Reddy) Dye 1978 is pathogenic to wheat, barley and rye but not to oat; X. campestris pv. secalis (Reddy, Godkin and Johnson) Dye 1978 is a pathogen of rye; $X$. campestris pv. cerealis (Hagborg) Dye 1978 is pathogenic to wheat, barley, rye, and oat (12); and $X$. campestris pv. phleipratensis (Wallin and Reddy) Dye 1978 is a pathogen of Phleum pratense (26). However, the host range of each pathovar has not been thoroughly defined and many grass species would be

Accepted for publication 23 May 1995.

Publication no. D-1996-1115-04R

(C) 1997 The American Phytopathological Society potential hosts for some of these pathovars in spite of the lack of evidence so far. Host ranges are not always as well characterized as definitions might suggest. In addition, biochemical and physiological characteristics are not usually sufficient for pathovar identification (9).

Alternative techniques including serology, analysis of total or membrane proteins using sodium dodecyl sulfate-polyacrylamide gel electrophoresis, fatty acid profiling, and DNA-DNA hybridization were used to tentatively differentiate pathovars of $X$. campestris $(4,25)$. When applied to the $X$. campestris strains responsible for the bacterial leaf streak of cereals, none of these methods proved to be successful for the identification of the pathovars previously defined $(4,24,25)$. As a result, various authors used the term "pathovar translucens" for the strains causing leaf streak on cereals and grasses (20). This designation remains controversial, however, since some strains of $X$. campestris, which are pathogenic to cereals, have heterogeneous characteristics including their host range. For example, in Iran, bacterial leaf streak of barley and wheat was first reported in the southeastern region of the country. The strains were shown to differ in host range and total protein electrophoretic patterns. From these characteristics and bacteriological features, the causal agents were identified as two pathovars of
$X$. campestris (2). The study was recently extended to 44 strains collected on cereals and grasses from all over Iran (1). Taking into account the ability or lack of ability to give rise to the disease on wheat, barley, rye, Bromus inermis, Lolium multiflorum, and Agropyron elongatum, the 44 strains were separated into two groups. Strains of the first group were virulent only on barley whereas the second group could infect all plants mentioned above except oat. It was then interesting to assess whether the two groups of strains could be differentiated from each other on the basis of other characteristics such as restriction fragment length polymorphism (RFLP).

Restriction endonuclease analysis (REA) and RFLP of plasmid and genomic DNAs have been used to differentiate pathovars among plant pathogenic bacteria. Using RFLP analyses, Lazo et al. (16) were able to differentiate $X$. campestris strains corresponding to 26 pathovars and the grouping thus achieved was closely correlated with that obtained for host specificity. Similar conclusions were reached in detailed investigations on the pathovars oryzae (17, 18), citri (13), zeae (22), vasculorum (21) and holcicola (23). In addition, RFLP proved to be useful for the identification of different clones within a pathovar. The clones were sometimes found to differ in relation to geographical origin $(17,21)$, date of sampling (6), aggressiveness (11), or other pathogenic traits (10).

In the investigation reported below, which included reference strains in addition to Iranian strains, the potential value of RFLP analysis to distinguish between the two groups of $X$. campestris strains among Iranian strains was evaluated.

\section{MATERIALS AND METHODS}

Bacterial strains and culture conditions. The Iranian strains used in this study are listed in Table 1 together with reference strains (obtained from H. Maraite and C. Bragard, Unité de Phytopathologie, UCL, Louvain-la-Neuve, Belgium). All strains were routinely grown on nutrient agar (NA, Difco, Detroit, MI) at $28^{\circ} \mathrm{C}$.

REA and RFLP analyses. For each strain, DNA was extracted using $1.5 \mathrm{ml}$ of a 24-h-old culture grown in Luria broth (10 $\mathrm{g}$ of tryptone, $5 \mathrm{~g}$ of yeast extract, and $5 \mathrm{~g}$ of $\mathrm{NaCl}$ per liter of distilled water). Extraction followed the procedure described 
by Arlat et al. (3). Digestions with the enzymes BamHI, BglII, EcoRI, HindIII and XhoI (Boehringer Mannheim Biochemica BP 59, 38242, Meylan, France) were carried out according to the supplier's instructions.

Restriction fragments were then separated by gel electrophoresis using $1 \%$ agarose gel equilibrated in TAE $(10 \mathrm{mM}$ Tris, $\mathrm{pH} 7.8,5 \mathrm{mM}$ sodium acetate, and $0.5 \mathrm{mM}$ EDTA) buffer at $8 \mathrm{~V}$ per $\mathrm{cm}$. After staining with ethidium bromide, the DNA bands were visualized and photographed under irradiation at $260 \mathrm{~nm}$, using an orange filter. DNA fragments were then transferred, according to the manufacturer's instructions, to nylon membrane Biodyne (Pall Biosupport, East Hills, NY) and hybridized with a probe consisting of either plasmid pIJ3225, described elsewhere (3), or plasmid pI10 kindly provided by M. J. Daniels (Sainsbury Laboratory, Norwich, UK).
Plasmid pIJ3225 carries a 29-kb insert that harbors most of the hrp gene cluster of $X$. campestris pv. campestris. This gene cluster is an essential pathogenicity determinant found in numerous gram-negative plant pathogenic bacteria (3). The second probe $\mathrm{pI} 10$ carries an approximately $20-\mathrm{kb}$ insert that harbors genes essential to the production of xanthan (M. J. Daniels, personal communication), an exopolysaccharide characteristic of $X$. campestris

Table 1. List of strains of Xanthomonas campestris from cereals and grasses used in this study and classification established according to pathovars, host range, and restriction fragment length polymorphism (RFLP) groups

\begin{tabular}{|c|c|c|c|c|c|c|c|}
\hline \multirow[b]{2}{*}{ Strain $^{a}$} & \multirow{2}{*}{$\begin{array}{l}\text { Pathovar or host } \\
\text { range group }\end{array}$} & \multirow{2}{*}{$\begin{array}{l}\text { RFLP } \\
\text { group }^{\mathbf{c}}\end{array}$} & \multirow[b]{2}{*}{ Host range $^{d}$} & \multicolumn{4}{|c|}{ Isolation source } \\
\hline & & & & Host & Year & Country & Referemce \\
\hline \multicolumn{8}{|l|}{ Reference strains } \\
\hline UPB449 & & & & & & & \\
\hline $\begin{array}{l}\text { (NCPPB973) } \\
\text { UPB453 }\end{array}$ & translucens & 3 & Wheat and barley & Hordeum vulgare & 1933 & USA & C. S. Reddy (USA) \\
\hline (NCPPB1944) & cerealis & 3 & Wheat and barley & Bromus inermis & 1941 & USA & A. C. Hayward (USA) \\
\hline UPB458 & & & & & & & \\
\hline (NCPPB2389) & hordei & 1 & Barley & Hordeum vulgare & 1970 & India & G. S. Shekhavat (India) \\
\hline UPB443 & & & & & & & \\
\hline (NCPPB2821) & undulosa & $2 \mathrm{~B}$ & Wheat and barley & Triticum turgidum & 1966 & Canada & J. Wilkie (New Zealand) \\
\hline UPB513 & translucens & $2 \mathrm{~B}$ & Wheat and barley & Tritico-secale & 1987 & Mexico & $\begin{array}{l}\text { E. Duveiller (CIMMYT, } \\
\text { Mexico) }\end{array}$ \\
\hline UPB522 & translucens & $2 \mathrm{~B}$ & Wheat and barley & Triticum aestivum & 1987 & Mexico & $\begin{array}{l}\text { E. Duveiller (CIMMYT, } \\
\text { Mexico) }\end{array}$ \\
\hline UPB545 & translucens & 1 & Barley & Hordeum vulgare & 1987 & Mexico & $\begin{array}{c}\text { E. Duveiller (CIMMYT, } \\
\text { Mexico) }\end{array}$ \\
\hline UPB676 & translucens & $2 \mathrm{~A}$ & Wheat and barley & Secale cereale & 1988 & South Africa & Smith (South Africa) \\
\hline UPB721 & cerealis & 3 & Wheat and barley & Bromus sp. & 1984 & Japan & $\begin{array}{c}\text { K. Miyagima (Hokkaido, } \\
\text { Japan) }\end{array}$ \\
\hline UPB727 & undulosa & $2 \mathrm{~A}$ & Wheat and barley & Tritico-secale & 1989 & Ethiopia & $\begin{array}{c}\text { C. Bragard (UCL, Bel- } \\
\text { gium) }\end{array}$ \\
\hline UPB763 & translucens & 1 & Barley & Hordeum vulgare & 1990 & USA & D. Sands (MSU, USA) \\
\hline UPB764 & translucens & 1 & Barley & Hordeum vulgare & 1990 & USA & D. Sands (MSU, USA) \\
\hline UPB797 & translucens & 1 & Barley & Hordeum vulgare & 1990 & Paraguay & $\begin{array}{l}\text { C. Bragard (UCL, Bel- } \\
\text { gium) }\end{array}$ \\
\hline UPB914 & translucens & 1 & Barley & Hordeum vulgare & 1990 & USA & B. Forster \\
\hline UPB916 & translucens & 1 & Barley & Hordeum vulgare & 1990 & USA & D. Sands (MSU, USA) \\
\hline UPB801 & translucens & 1 & Barley & Hordeum vulgare & 1990 & Paraguay & $\begin{array}{c}\text { C. Bragard (UCL, Bel- } \\
\text { gium) }\end{array}$ \\
\hline UPB917 & translucens & 1 & Barley & Hordeum vulgare & 1990 & USA & D. Sands (MSU, USA) \\
\hline \multicolumn{8}{|l|}{ Iranian strains } \\
\hline $\begin{array}{c}\text { IBLS1, } 2,3,4,5,6 \\
7,8,9,10,13 \\
14,15 \text { and } 16\end{array}$ & Group I & 1 & Barley & Hordeum vulgare & $\begin{array}{c}1988 \text { to } \\
1990\end{array}$ & Iran & A. Alizadeh et al. (1995) \\
\hline $\begin{array}{l}\text { IBLS11, 17, 18, 19, } \\
21 \text { and } 30\end{array}$ & Group II & $2 \mathrm{~B}$ & W., B., Ag., Br., L., $S$ & Triticum aestivum & $\begin{array}{c}1988 \text { to } \\
1990\end{array}$ & Iran & A. Alizadeh et al. (1995) \\
\hline $\begin{array}{c}\text { IBLS } 12,20,22,23, \\
24,25,26,27, \\
28,29 \text { and } 31\end{array}$ & Group II & $2 \mathrm{~A}$ & W., B., Ag., Br., L., $S$ & Triticum aestivum & $\begin{array}{c}1988 \text { to } \\
1990\end{array}$ & Iran & A. Alizadeh et al. (1995) \\
\hline IBLS 32 & Group II & $2 \mathrm{~A}$ & W., B., Ag., Br., L., $S$ & Aegilops sp. & 1990 & Iran & A. Alizadeh et al. (1995) \\
\hline IBLS 33 & Group II & $2 \mathrm{~A}$ & W., B., Ag., Br., L., $S$ & Aegilops ventricosa & 1990 & Iran & A. Alizadeh et al. (1995) \\
\hline IBLS 34 & Group II & $2 \mathrm{~A}$ & W., B., $A g ., B r ., L ., S$ & Aegilops cylindrica & 1990 & Iran & A. Alizadeh et al. (1995) \\
\hline IBLS 35 & Group II & $1 \mathrm{~A}$ & W., B., Ag., Br., L., $S$ & Aegilops cylindrica & 1990 & Iran & A. Alizadeh et al. (1995) \\
\hline IBLS 36 & Group II & $2 \mathrm{~A}$ & W., B., Ag., Br., L., $S$ & Bromus sp. & 1990 & Iran & A. Alizadeh et al. (1995) \\
\hline IBLS 37 & Group II & $2 \mathrm{~A}$ & W., B., $A g ., B r ., L ., S$ & Bromus tectorum & 1990 & Iran & A. Alizadeh et al. (1995) \\
\hline IBLS 38 & Group II & $1 \mathrm{~A}$ & W., B., Ag., Br., L., $S$ & Hordeum maritimum & 1990 & Iran & A. Alizadeh et al. (1995) \\
\hline IBLS 39 & Group II & $1 \mathrm{~A}$ & W., B., $A g ., B r ., L ., S$ & Hordeum maritimum & 1990 & Iran & A. Alizadeh et al. (1995) \\
\hline IBLS 40 & Group I & 1 & Barley & Hordeum sp. & 1990 & Iran & A. Alizadeh et al. (1995) \\
\hline IBLS 41 & Group II & $2 \mathrm{~A}$ & W., B., $A g ., B r ., L ., S$ & Lolium strictum & 1990 & Iran & A. Alizadeh et al. (1995) \\
\hline IBLS 42 & Group II & $2 \mathrm{~A}$ & W., B., Ag., Br., L., $S$ & Lolium strictum & 1990 & Iran & A. Alizadeh et al. (1995) \\
\hline IBLS 43 & Group II & $2 \mathrm{~A}$ & W., B., Ag., Br., L., $S$ & Sclerochloa dura & 1989 & Iran & A. Alizadeh et al. (1995) \\
\hline IBLS 44 & Group II & $2 \mathrm{~A}$ & W., B., Ag., Br., L., $S$ & Heteranthelium sp. & 1990 & Iran & A. Alizadeh et al. (1995) \\
\hline IBLS 45 & Group III & 3 & W., B., $A g ., B r ., L ., S$ & Bromus sp. & 1990 & Iran & $\begin{array}{l}\text { A. Alizadeh et al., unpub- } \\
\text { lished data }\end{array}$ \\
\hline
\end{tabular}

a NCPPB: National Collection of Plant Pathogenic Bacteria, Harpenden, UK; UPB: "Unité de Phytopathologie" Bacterial Collection, UCL, Louvain-laNeuve, Belgium; IBLS: Iranian strains of bacterial leaf streak of cereals.

${ }^{\mathrm{b}}$ Grouping based on the host range.

${ }^{\mathrm{c}}$ Grouping based on RFLP results.

d W.: wheat; B.: barley; Ag.: Agropyron elongatum; Br.: Bromus inermis; L.: Lolium multiflorum; S.: Secale cereale. 
that plays a major role in bacterial pathogenicity (19). The probes were labeled with $\left[\alpha^{32} \mathrm{P}\right] \mathrm{dCTP}\left(3,000 \mathrm{Ci} . \mathrm{mM}^{-1}\right)$. Hybridizations proceeded for $15 \mathrm{~h}$ at 37 or $42^{\circ} \mathrm{C}$ in the presence of $5 \times \mathrm{SSC}(1 \times \mathrm{SSC}$ is $0.15 \mathrm{M} \mathrm{NaCl}$ plus $0.015 \mathrm{M}$ sodium citrate $\mathrm{pH} 7.0$ ) and $50 \%$ formamide and were followed by washing at room temperature in the presence of $2 \times$ SSC. Autoradiographic exposures lasted from 2 to 7 days in the presence of intensifying screens.

Similarity coefficient analysis. In order to estimate the relatedness between strains, similarity coefficients were established for all pairwise combinations of strains and calculated according to the formula (2Nxy) $(100) /(N x+N y)$ where $N x$ and $N y$ represent the number of unique restriction fragments corresponding to the organism $x$ or $y$, respectively, and $N x y$ is the number of fragments common to both $x$ and $y$. The grouping of the strains, which was based on the similarity coefficients, relied on a hierarchical classification algorithm using the average weighed link method. The coefficients were used to generate dendrograms to characterize similarities between strains (6).

\section{RESULTS AND DISCUSSION}

REA analysis. Analysis of the banding patterns of the genomic DNAs of the Iranian strains and of the reference strains was carried out after digestion with the restriction endonucleases BamHI, EcoRI, $B g l$ II, HindIII, and XhoI and corroborated the existence of different groups among the strains studied. Although the same conclusions could be drawn irrespective of the restriction enzymes used, BamHI, BglII, and $\mathrm{XhoI}$ were most suitable as they generated populations of fragments that were easier to analyze (data not shown). Polymorphism occurred among the strains in the experiments and the strains could be grouped in relation to their banding patterns. Interestingly, the grouping thus obtained correlated with the grouping previously established from pathogenicity testing. Strains from group I formed a homogeneous group with closely conserved banding patterns for all the enzymes tested. Reference strains UPB763, UPB764, and UPB458, which were pathogenic to barley but not to wheat (5), belonged to group I and were easily differentiated from group II strains which had a wider host range. Occasional minor differences in the banding patterns could be detected among strains of group II, suggesting that this group might not be as homogeneous as group I (data not shown). Reference strains UPB513, UPB522, UPB727, UPB443, and UPB676, which had been shown to infect both wheat and barley (5), were clearly related to group II. The pattern observed for strain IBLS 45, which is pathogenic to Bromus but is weakly pathogenic to barley, wheat, rye, Lolium multiflorum, and Agropyron elongatum and is not pathogenic to

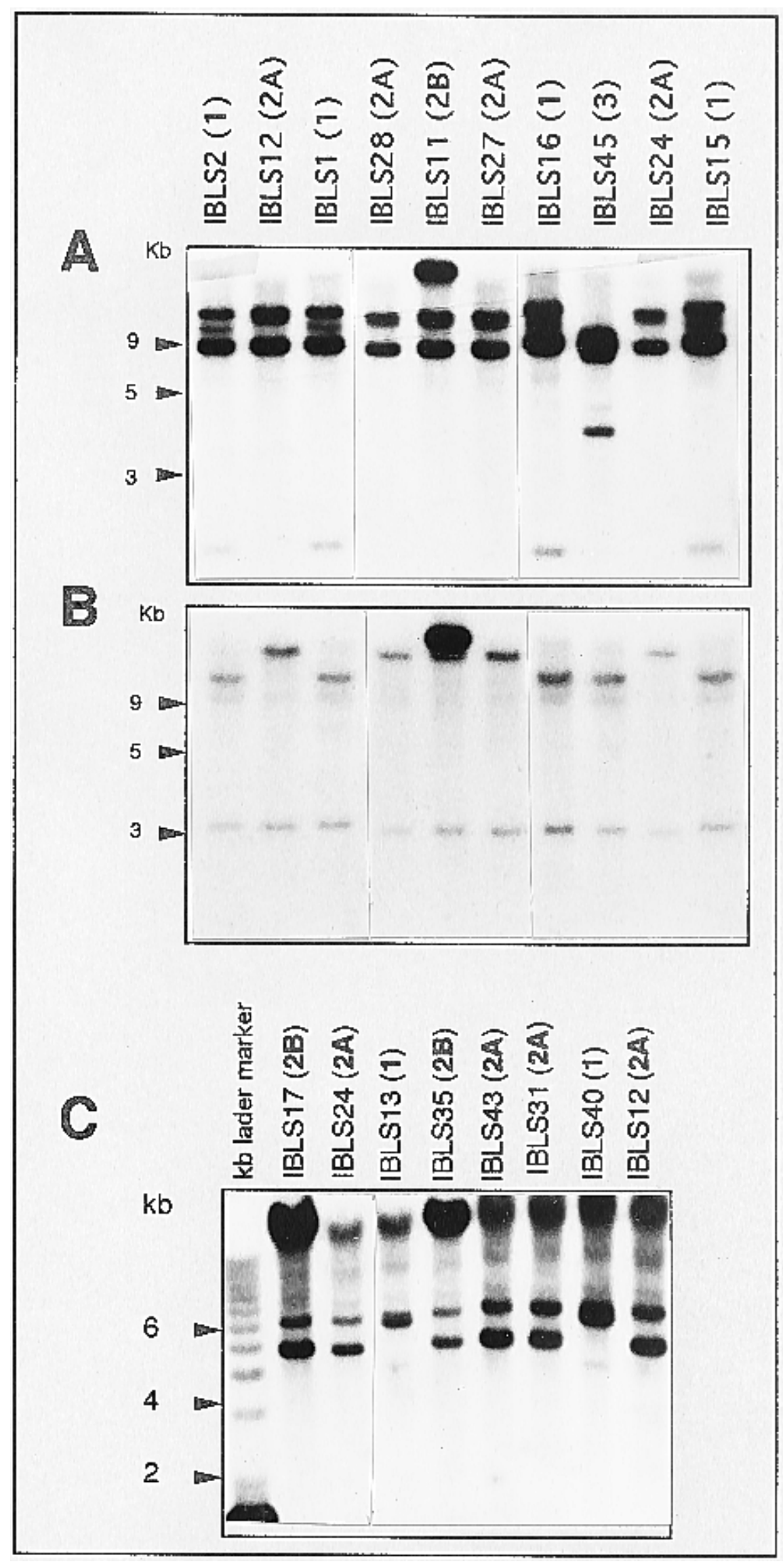

Fig. 1. Hybridization of Southern blot of genomic DNA of representative Xanthomonas campestris strains from cereals and grasses with probes $\mathrm{pIJ} 3225$ and pI10. Genomic DNAs digested with BamHI and probed (A) with pIJ3225 and (B) with pI10 or (C) digested with BgIII and probed with pIJ3225. Restriction fragment length polymorphism groups were indicated between brackets. 
oat (A. Alizadeh, unpublished data), was clearly different from those of the strains belonging to groups I and II. When compared with reference strains, IBLS 45 appeared to be related to strains UPB449, UPB453, and UPB721, and thus belonged to the third group of strains, thereafter referred to as group III.

RFLP analysis. RFLP analysis of total genomic DNA was performed using plasmid probes pIJ3225 and pI10, both carrying pathogenicity determinants from $X$. campestris pv. campestris. As already observed with REA, the use of restriction enzymes EcoRI and HindIII was not very relevant since most of the hybridizing fragments had a high molecular weight and were thus poorly resolved by gel electrophoresis. In contrast, using BamHI, BglII, or XhoI, the two probes showed the occurrence of a set of 5 to 17 restriction fragments that were well distributed over the entire length of the gel, thus making it possible to compare the various strains (Fig. 1).

The use of BamHI in combination with probe pI10 allowed three groups of strains to be distinguished (data not shown). Similar conclusions could be drawn from the analysis of the results obtained from the BamHI/pIJ3225 and BglII/pIJ3225 combinations. The data obtained from the BamHI/pI10, BamHI/pIJ3225, and BglII/ pIJ3225 hybridizations were combined to generate the dendrogram presented in Figure 2. Sixty-one out of the 62 strains studied could be classified into three groups defined at a cut-off of about $63 \%$ similarity. These three groups exactly matched the previous grouping of the strains based on REA analysis. RFLP group 1 contains all the strains, including reference strains, which had been shown to be pathogenic to barley but not to other plants tested (Table 1). RFLP group 2, which comprises all the strains that are pathogenic to all the plants tested except oat (Table 1), can be further divided into subgroups $2 \mathrm{~A}$ and $2 \mathrm{~B}$ at the cut-off of about $76 \%$ similarity. The subgroups $2 \mathrm{~A}$ and $2 \mathrm{~B}$ had not previously been distinguished based on pathogenicity traits, biochemical and physiological characters, or host specificity (2). The remaining strains, which were previously in REA group III, formed a homogeneous group (RFLP group 3). Among the four strains belonging to RFLP group 3, three (UPB453, UPB721 and IBLS45) had been isolated from Bromus spp. (Table 1).

A single strain, IBLS26, did not fit into any of these groups since, according to BamHI/pIJ3225 hybridization data, this strain would fit into RFLP group 1 whereas BamHI/pI10 hybridization data suggested it would fit into RFLP group 2. REA analysis also suggested this strain could be classified in group II, indicating that most of the genome of this strain is similar to the genome of group II strains: IBLS26 most likely results from a genetic transfer of the region flanking the hrp gene cluster in a group I strain into a strain belonging to group II.

The results obtained suggest that RFLP analysis can be useful for differentiating between $X$. campestris strains isolated from cereals. This technique allowed strains that are pathogenic only to barley (and that might therefore belong to the pathovar hordei) to be distinguished from strains with a wider host range. As the differences between strains belonging to RFLP groups 1 and 2 were smaller than the differences between these two groups and RFLP group 3, the question of whether strains of groups 2 and 3 actually correspond to two different pathovars is thus raised.

It is to be noted that when plasmid pIJ3225 (originating from X. campestris pv. campestris) was used as a probe, hybridization signals were weak, compared with those observed when using the pI10 probe. Interestingly, it was learned (D. W. Gabriel, personal communication) that $X$. campestris pv. translucens genomic DNA hybridized weakly with probe pUFM 2110 , which consists of $X$. campestris pv. citrumelo hrp genes (15), compared with the hybridization signal obtained with plasmid pVir2, which carries hrp genes of Pseudo-
Fig. 2. Grouping of Iranian strains of Xanthomonas campestris and reference strains according to the similarity coefficients calculated from restriction fragment length polymorphism (RFLP) analysis of BamHI digests of genomic DNAs probed with plasmids pI10 and pIJ3225 and of BglII digests probed with pIJ3225. RFLP1, 2A, 2B, and 3 refer to Iranian strains belonging to RFLP groups 1, 2A, $2 \mathrm{~B}$, and 3, respectively. The strains belonging to each RFLP group are shown in Table 1. 
monas solanacearum. Therefore, in future work it might be worthwhile to use either plasmid pVir2 or a $X$. campestris pv. translucens hrp probe instead of plasmid pIJ3225 as the hybridization probe for RFLP analysis of the $X$. campestris pathovars that are pathogenic to cereals.

Though limited, the RFLP analyses showed the occurrence of some variability among strains belonging to the same RFLP group or subgroup. Thus, genetically distinct strains do exist within each group and the possibility that the Iranian strains used in this study may be siblings of a single strain clonally amplified during an epidemic spread of the disease can be ruled out. The existence of such a variety of strains in Iran could be expected, since cereals originate from this part of the world and the coevolution of these plants with their pathogens could proceed for a long time.

\section{ACKNOWLEDGMENTS}

The authors would like to thank Jean-Louis Charpenteau (INRA, Toulouse, France) for valuable help in analysis of RFLP patterns, Michael J. Daniels (Sainsbury Laboratory, Norwich, UK) for supplying plasmid pI10 prior to publication, $\mathrm{H}$. Maraite and C. Bragard (UCL, Louvain-La-Neuve, Belgium) for supplying reference strains, and David Barker for correcting the manuscript. This work was supported by the Ministry of Construction Jihad of the Islamic Republic of Iran (grant number 3045050 to the first author).

\section{LITERATURE CITED}

1. Alizadeh, A., Barrault, G., and Sarrafi, A. 1995. Identification of bacterial leaf streak of cereals by their phenotypic characteristics and host range in Iran. Eur. J. Plant Pathol. 101:225-229.

2. Alizadeh, A., and Rahimian, H. 1989. Bacterial leaf streak of Gramineae in Iran. EPPO Bull. 19:113-117.

3. Arlat, M., Gough, C. L., Barber, C. E., Boucher, C., and Daniels, M. J. 1991. Xanthomonas campestris contains a cluster of $h r p$ genes related to the larger $h r p$ cluster of Pseudomonas solanacearum. Mol. PlantMicrobe Interact. 4:593-601.

4. Azad, H., and Schaad, N. W. 1988. Serological relationships among membrane proteins of strains of Xanthomonas campestris pv. translucens. Phytopathology 78:272-277.

5. Bragard, C., and Maraite, H. 1992. Pathogenic variation in Xanthomonas campestris pv. undulosa. Pages 801-812 in Proc. Int. Conf. Plant Pathogenic Bacteria, 8th. Versailles France.

6. Cook, D., Barlow, E., and Sequeira, L. 1989. Genetic diversity of Pseudomonas solanacearum: Detection of restriction fragment length polymorphisms with DNA probes that specify virulence and the hypersensitive response. Mol. Plant-Microbe Interact. 2:113121.

7. Duveiller, E. 1989. Research on Xanthomonas translucens of wheat and triticale at CIMMYT. EPPO Bull. 19:97-103.

8. Duveiller, E., and Maraite, H. 1993. Study on yield loss due to Xanthomonas campestris pv. undulosa in wheat under high rainfall temperate conditions. Z. Pflanzenkr. Pflanzenschutz 100:453-459.

9. Dye, D. W. 1962. The inadequacy of the usual determinative tests for the identification of Xanthomonas spp. N.Z. J. Sci. 5:393-416.

10. Gabriel, D. W., Hunter, J. E., Kingsley, M. T., Miller, J. W., and Lazo, G. R. 1988. Clonal population structure of Xanthomonas campestris and genetic diversity among citrus canker strains. Mol. Plant-Microbe Interact. 1:59-65.

11. Gottwald, T. R., Alvarez, A. M., Hartung, J. S., and Benedict, A. A. 1991. Diversity of Xanthomonas campestris pv. citrumelo strains associated with epidemics of citrus bacterial spot in Florida citrus nurseries: Correlation of detached leaf, monoclonal antibody, and restriction fragment length polymorphism assays. Phytopathology 81:749-753.

12. Hagborg, W. A. F. 1942. Classification revision in Xanthomonas translucens. Can. J. Res. Sect. C. 20:312-326.

13. Hartung, J. S., and Civerolo, E. L. 1989. Restriction fragment length polymorphisms distinguish Xanthomonas campestris strains isolated from Florida citrus nurseries from $X$. c. pv. citri. Phytopathology 79:793-799.

14. Jones, L. R., Johnson, A. G., and Reddy, C. S. 1917. Bacterial blight of barley. J. Agric. Res. (Washington, D.C.) 11:625-644.

15. Kingsley, M. T., Gabriel, D. W., Marlow, G. C., and Roberts, P. D. 1993. The opsX locus of Xanthomonas campestris affects host range and biosynthesis of lipopolysaccharide and extracellular polysaccharide. J. Bacteriol. 175: 5839-5850.
16. Lazo, G. R., Roffey, R., and Gabriel, D. W. 1987. Pathovars of Xanthomonas campestris are distinguishable by restriction fragment length polymorphism. Int. J. Syst. Bacteriol. 37:214-221.

17. Leach, J. E., Rhoads, M. L., Vera Cruz, C. M., White, F. F., Mew, T. W., and Leung, H. 1992. Assessment of genetic diversity and population structure of Xanthomonas oryzae pv. oryzae with a repetitive DNA element. Appl. Environ. Microbiol. 58:21882195.

18. Leach, J. E., White, F. F., Rhoads, M. L., and Leung, H. 1990. A repetitive DNA sequence differentiates Xanthomonas campestris pv. oryzae from other pathovars of Xanthomonas campestris. Mol. Plant-Microbe Interact. 3: 238-246.

19. Leigh, J. A., and Coplin, D. L. 1992. Exopolysaccharides in plant-bacterial interactions. Annu. Rev. Microbiol. 46:307-346.

20. Mellano, V. J., and Cooksey, D. A. 1988. Development of host range mutants of Xanthomonas campestris pv. translucens. Appl. Environ. Microbiol. 54:884-889.

21. Qhobela, M., and Claflin, L. E. 1992. Eastern and Southern African strains of Xanthomonas campestris pv. vascularum are distinguishable by restriction fragment length polymorphism of DNA and polyacrylamide gel electrophoresis of membrane proteins. Plant Pathol. 41:113-121.

22. Qhobela, M., Claflin, L. E., and Nowell, D. C. 1990. Evidence that Xanthomonas campestris pv. zeae can be distinguished from other pathovars capable of infecting maize by restriction fragment length polymorphism of genomic DNA. Can. J. Plant Pathol. 12:183186.

23. Qhobela, M., Leach, J. E., Claflin, L. E., and Pearson, D. L. 1991. Characterization of strains of Xanthomonas campestris pv. holcicola by PAGE of membrane proteins and by REA and RFLP analysis of genomic DNA. Plant Dis. 75:32-36.

24. Stead, D. E. 1989. Grouping of Xanthomonas campestris pathovars of cereals and grasses by fatty acid profiling. EPPO Bull. 19:57-68.

25. Vauterin, L., Yang, P., Hoste, B., Pot, B., Swings, J., and Kersters, K. 1992. Taxonomy of xanthomonads from cereals and grasses based on SDS-PAGE of proteins, fatty acid analysis and DNA hybridization. J. Gen. Microbiol. 138:1467-1477.

26. Wallin, N. W., and Reddy, C. S. 1945. A bacterial streak disease of Phleum pratense L. Phytopathology 35:937-939. 